\title{
Mechanical modulation of a human plasma based skin scaffold via reactive via reactive multi-arm polyethylene glycols Áccesit Congreso SIBB 2016
}

\author{
R. CORRALES ${ }^{1 *}$, M. SIKORSKI ${ }^{1^{*}}$, M. GARCÍA ${ }^{1,2,3}$, D. VELASCO ${ }^{1,2}$, J.L. JORCANO ${ }^{1,3}$ \\ ${ }^{1}$ Department of Bioengineering and Aerospace, Universidad Carlos III de Madrid (UC3M), Spain \\ ${ }_{2}^{2}$ Instituto de Investigación Sanitaria de la Fundación Jiménez Díaz, Madrid, Spain \\ ${ }^{3}$ Division of Epithelial Biomedicine, CIEMAT-CIBERER, Madrid, Spain \\ "These authors contributed equally
}

\begin{abstract}
Autologous human plasma-based dermo-epidermal skin equivalents have been designed over the past decade to treat burns and surgical wounds; however, poor mechanical properties including fragility during handling, and shrinking during culture and implantation persist and demand creative solutions. This article investigates the mechanical modulation of human plasma-based skin scaffolds with the introduction of an interpenetrating biodegradable polyethylene glycol (PEG) network composed of 4-arm succinimidyl glutarate terminated PEG (4SG-PEG) and 4-arm amine terminated $P E G$ (4A-PEG), each with a molecular weight of $10 \mathrm{kDa}$. The physical properties of the PEG-fibrin network hydrogels were characterized via gelation time, temporal mass swelling, and protein release. Additionally, viability of primary human fibroblasts ( $h F B s$ ) and keratinocytes ( $h K C s$ ) was assessed by Alamar Blue and MTS assays, respectively. The results obtained suggested that the incorporation of reactive multi-arm PEGs as an interpenetrating biodegradable PEG network modulated the physical behaviour by inducing swelling and increasing scaffold strength without significantly decreasing cell viability. These results warrant further investigation into this platform as an approach to influence skin scaffold properties.
\end{abstract}

Keywords: Scaffold, skin engineering, biosynthetic hydrogel, human plasma, fibrin hydrogel, 4-arm polyethylene glycol (PEG)

\section{Resumen}

Equivalentes dermo-epidérmicos basados en plasma humano autólogo han sido diseñados a lo largo de la última década con el objetivo de tratar quemaduras y heridas quirúrgicas; aun así, las malas propiedades mecánicas como son la fragilidad o la contracción durante el cultivo y la implantación persisten y requieren soluciones. Este artículo investiga la modulación mecánica de equivalentes dermo-epidérmicos basados en plasma humano mediante la introducción de una red tridimensional ( $3 D$ ) polimérica interpenetrante y biodegradable compuesta por polietilenglicol tetraglutarato de succinimidil (4SG-PEG) y polietilenglicol tetra-amino (4A-PEG), con pesos moleculares de 10kDa. Las propiedades fisicas de estos hidrogeles de fibrina y PEG fueron caracterizadas mediante la cuantificación de grupos aminos libres, el tiempo de gelificación, el hinchamiento de forma temporal y la liberación de proteinas. Además, la viabilidad de fibroblastos y queratinocitos primarios humanos fueron estudiadas mediante los ensayos Alamar Blue y MTS respectivamente. Los resultados obtenidos sugieren que mediante la introducción de una red interpenetrante basada en PEG y fibrina, las propiedades mecánicas de los geles de fibrina fueron moduladas positivamente, sin disminuir significativamente la viabilidad celular. Estos resultados prometen futuras investigaciones para mejorar las propiedades mecánicas de estos equivalentes dermo-epidérmicos.

Palabras clave: scaffold, ingeniería de tejidos, hidrogeles biosintéticos, plasma humano, hidrogel de fibrina, polietilenglicol

Correspondencia:

Diego Velasco y José Luis Jorcano.

E-mail: divelasc@ing.uc3m.es, jjorcano@ing.uc3m.es 


\section{Introduction}

Patients with skin injuries caused by burns, chronic ulcers, infections, cancer surgery, and other genetic and somatic diseases require effective treatment to prevent morbidity or mortality. Autologous skin grafts are the standard of treatment for severe and extensive burns, and have been used in patients with sufficient healthy tissue to cover the wound $(1,2)$. When $50 \%$ to $60 \%$ of the patient's body surface area is damaged, not enough skin is available to autograft, and other treatments are considered (3-5). Grafts from other patients, known as allografts can be used as temporary or permanent wound covers to avoid dehydration and infections. The major disadvantage regarding allografts is that when they become vascularized the immunogenic epithelial cells may trigger the immune response of the host and the graft could be rejected (6). Another alternative is the use of cultured autologous epithelial autografts (CEA) but their results are far from ideal since they are limited by the fragility and difficulty of handling, unpredictable take rate and sensitivity to mechanical shearing forces for at least two months post grafting (7).

In response to these limitations, new approaches for skin engineering have been tested and developed in recent years. These advances have led to the development of more sophisticated laboratory-grown skin substitutes containing dermal and epidermal components that interact dynamically with each other during in vitro maturation and further after transplantation $(8,9)$. Over the past decade, our group has generated a human plasma-based autologous bilayered (including dermis and epidermis) skin model to treat burns and surgical wounds yielding good clinical results $(10,11)$. However, these plasmaderived fibrin hydrogels suffer from shrinking during transport, fragility, and high degradation rates caused by poor mechanical properties. The combination of plasma-derived fibrin with other synthetic and natural polymers has been considered for improving the hydrogel mechanical properties without compromising biocompatibility (12-14).
One of the most widely investigated polymers is polyethylene glycol (PEG) due to its unique properties, such as solubility in both water and organic solvents, nontoxicity, low protein adhesion and nonimmunogenicity (15). It is synthesized in a wide range of molecular weights, and has the ability to attach to a variety of reactive functional groups such as carboxyl, thiol and acrylate, or to other molecules or bioactive agents through its terminal alcohol group, which greatly increase applications of PEG $(16,17)$. Multi-arm PEG derivatives such as 4-arm PEGs and star PEGs are also prepared and commonly employed in the formation of hydrogels for various applications such as controlled drug release $(18,19)$, wound healing $(20)$, tissue sealing $(21,22)$ and cell encapsulation (23). In addition, amine reactive multi-arm PEG platforms have previously been investigated as tissue adhesives, surgical sealants, and hemostatic agents, and have demonstrated excellent strength as network gels $(21,24)$. The described research project aimed to improve the mechanical properties of these scaffolds by using two synthetic PEGs: amine reactive succinimidyl glutarate terminated 4-arm PEG (4SG-PEG) and amine terminated 4-arm PEG (4A-PEG), which react covalently with fibrinogen, plasma proteins, and each other to form a PEG-fibrin network hydrogel.

\section{Materials and methods}

\section{Materials}

Fresh frozen human plasma was provided by voluntary donors of the Centro Comunitario de Tejidos del Principado de Asturias (CCST) and was obtained according to the standards of the American Association of Blood Banks (25). Tranexamic acid (Amchafibrin, Fides- Ecopharma) was used as received. Sodium chloride $(\mathrm{NaCl})$, calcium chloride $\left(\mathrm{CaCl}_{2}\right)$, phosphate-buffered saline (PBS, $\mathrm{pH}$ 7.4), and bovine serum albumin (BSA) were purchased from Sigma-Aldrich. 4-arm polyethylene glycol succinimidyl glutarate (4SGPEG, MW 10,000) and 4-arm polyethylene glycol propylamine (4A-PEG, MW 10,000) were purchased from JenKem Technology Co. and NOF America Corporation, respectively. 


\section{Methods}

Plasma-PEG hydrogel preparation

Plasma-derived fibrin hydrogels (without PEG) were prepared following the protocol created by Llames et al. (10). This protocol was modified to incorporate a PEG network composed of 4SG-PEG and 4A-PEG in a 1:1 molar ratio with concentrations between 0.125 and $1 \%(\mathrm{w} / \mathrm{v})$ of total PEG in the plasma hydrogels (Table 1), while final concentration of fibrinogen, tranexamic acid and $\mathrm{CaCl}_{2}$ were kept constant at $0.12 \%, 0.008 \%$ and $0.08 \%(\mathrm{w} / \mathrm{v})$ respectively.

In order to prepare $2.046 \mathrm{~mL}$ of hydrogel solution, $20.46 \mathrm{mg}$ of $4 \mathrm{SG}-\mathrm{PEG}$ and $4 \mathrm{~A}-\mathrm{PEG}$ were weighted, and plasma was thawed at $37^{\circ} \mathrm{C}$. A volume of $994 \mu \mathrm{l}$ of plasma was introduced in a $15 \mathrm{~mL}$ falcon, followed by $16 \mu \mathrm{l}$ of tranexamic acid (amchafibrin). Next, the $20.46 \mathrm{mg}$ of $4 \mathrm{~A}-\mathrm{PEG}$ were dissolved in $600 \mu \mathrm{l}$ of $0.9 \% \mathrm{NaCl}$. From this volume, $300 \mu$ l was added to the plasma solution, plus another $272 \mu \mathrm{l}$ of $\mathrm{NaCl}$. In a separate eppendorf, $164 \mu \mathrm{l}$ of $1 \% \mathrm{CaCl}_{2}$ was added. The $20.46 \mathrm{mg}$ of $4 \mathrm{SG}$ PEG were dissolved in $600 \mu \mathrm{l}$ of $\mathrm{NaCl}$, from which $300 \mu$ were added to the $\mathrm{CaCl} 2$. The eppendorf solution was then added to the falcon solution, vortexed and divided into three equal gels of $682 \mu \mathrm{l}$ each in $19 \mathrm{~mm}$ vials. In this way, $1 \% \mathrm{w} / \mathrm{v}$ gels were created (Figure 1).

\begin{tabular}{|cccc|}
\hline Abbreviation & $\begin{array}{c}\text { 4SG-PEG content } \\
(\% \mathbf{~ w} / \mathbf{v})\end{array}$ & $\begin{array}{c}\text { 4A-PEG content } \\
(\% \mathbf{~ w} / \mathbf{)})\end{array}$ & $\begin{array}{c}\text { 4SG-PEG : 4A-PEG } \\
\text { Weight Ratio }\end{array}$ \\
\hline $0.125 \%$ PEG & $0.0625 \%$ & $0.0625 \%$ & $1: 1$ \\
\hline $0.25 \%$ PEG & $0.125 \%$ & $0.125 \%$ & $1: 1$ \\
\hline $0.5 \%$ PEG & $0.25 \%$ & $0.25 \%$ & $1: 1$ \\
\hline $1 \%$ PEG & $0.5 \%$ & $0.5 \%$ & $1: 1$ \\
\hline
\end{tabular}

Table 1. Different tested gel compositions, showing total 4SG-PEG and 4A-PEG content in each plasma-PEG hydrogel.

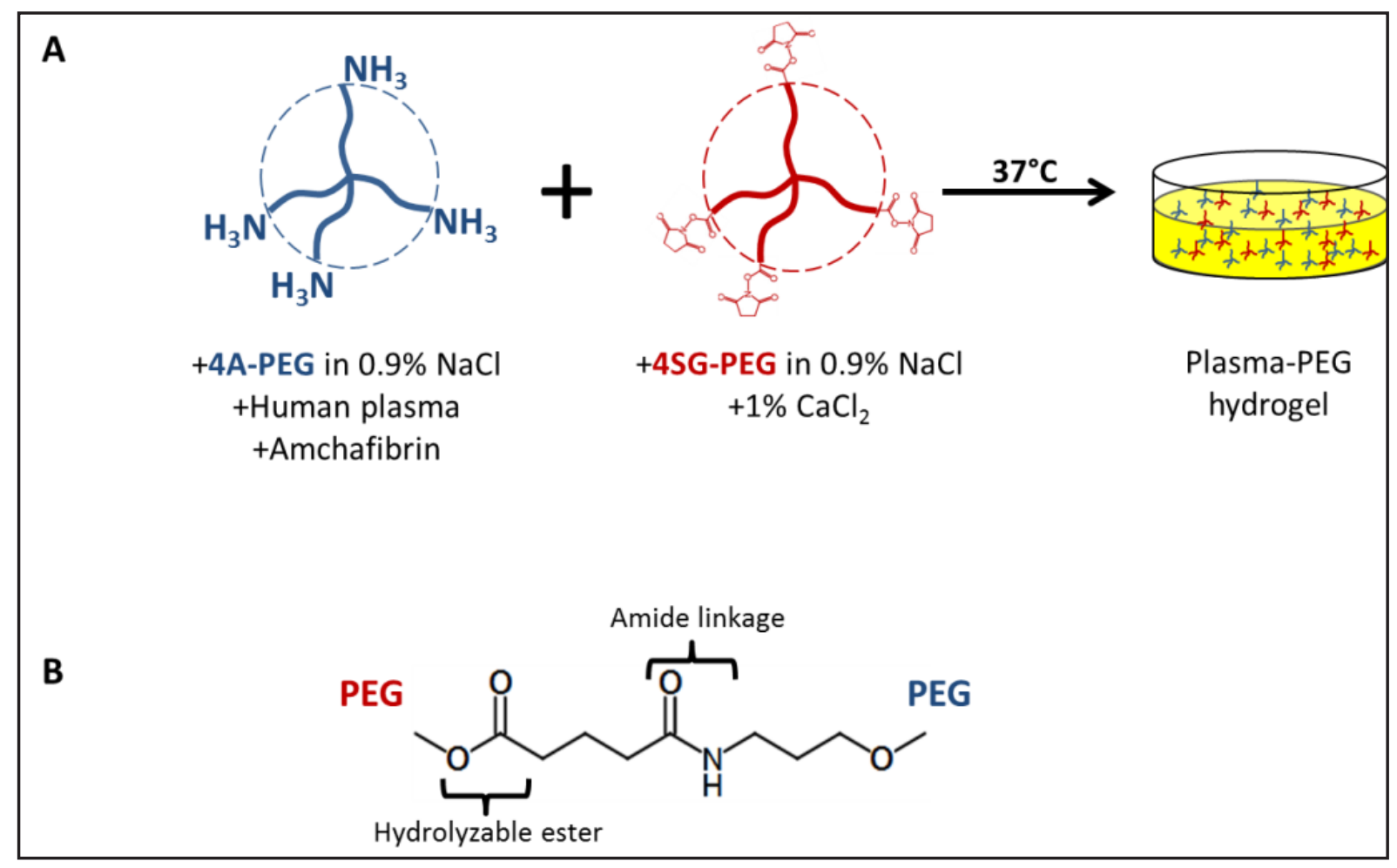

Figure 1. A. Schematic of plasma-PEG gel synthesis. 4A-PEG is dissolved in $0.9 \% \mathrm{NaCl}$ and combined with human plasma and amchafibrin. Separately, 4SG-PEG is dissolved in $0.9 \% \mathrm{NaCl}$ and further added to $1 \% \mathrm{CaCl}_{2}$. Both solutions are combined, and left undisturbed at $37^{\circ} \mathrm{C}$ until polymerization occurs. B. Schematic of the reaction between 4A-PEG and 4SG-PEG. 
The remaining 4A-PEG and 4SG-PEG solutions were diluted by half by adding another $300 \mu \mathrm{l}$ of $\mathrm{NaCl}$, and the same protocol was followed, creating $0.5 \% \mathrm{w} / \mathrm{v}$ PEG gels. The same dilution procedure was carried out to create $0.25 \%$ and $0.125 \% \mathrm{w} / \mathrm{v}$ plasma PEG hydrogels. Gel solutions were vortexed between each addition. Gels were incubated in a $37^{\circ} \mathrm{C}$ oven with $5 \% \mathrm{CO}_{2}$ until gelation occurred.

\section{Gelation Time}

Formation of gels and gelation times were confirmed by inversion of the vial. Once the gels were prepared, they were placed in an incubator at $37^{\circ} \mathrm{C}$, and gelation was checked every 30 seconds by slightly tilting the vial. The experiments were performed in triplicate.

\section{Swelling studies}

Gels were detached from the vials and transferred to a P35 tissue culture plate (Corning). Excess liquid was removed by micropipette aspiration, and mass was recorded. Swelling measurements were taken at different time points: $0,1,2,4,6,24,48$ and 72 hours, followed by 10 days and 17 days. After each time point, gels were covered in $3 \mathrm{~mL} 1 \mathrm{XPBS}$ and they were placed in the incubator at $37^{\circ} \mathrm{C}$ until the next measurement. Swelling ratio was computed with the equation:

$$
\begin{array}{r}
S R=M-M \\
M-M
\end{array}
$$

Where $M_{s}$ is the mass of the swollen gel, $M_{p}$ is the mass of the P35 petri dish and $\mathrm{M}_{\mathrm{i}}$ is the initial mass of the gel.

\section{Bradford Assay}

The Bradford protein assay (Bio-Rad Protein Assay, Bio-Rad) was performed at time points: $1,2,4,6,24$, and 48 hours, in order to quantify the amount of protein release from gels. At every time point, a sample of $20 \mu \mathrm{L}$ of 1XPBS from each gel was taken and added to $780 \mu \mathrm{L}$ of fresh 1 XPBS. Finally, $200 \mu \mathrm{L}$ of Bradford reagent was added. A standard curve of bovine serum albumin (BSA) was carried out to determine the protein content. Absorbance was measured with Biowave II (Bio- chrom) spectrophotometer at $695 \mathrm{~nm}$. This assay was performed simultaneously with the swelling study.

\section{Embedded Human Fibroblast Viability}

Primary human fibroblasts (hFBs) were embedded and their viability was quantified. Cells were routinely grown in Dubecco's Modified Eagle's Medium (DMEM) (Sigma Aldrich, Ireland) supplemented with $10 \%$ fetal bovine serum (FBS) and 1\% Penicillin/Streptomycin $(\mathrm{P} / \mathrm{S})$. This medium was changed every 3 days, and cells were maintained at $37^{\circ} \mathrm{C}, 5 \% \mathrm{CO}_{2}$.

The plasma-PEG gel preparation protocol was slightly modified in order to encapsulate hFBs in the hydrogels. First of all, medium was removed from plated hFBs, which were then detached using $1 \mathrm{~mL}$ of Trypsin (Sigma Aldrich). $5 \mathrm{~mL}$ of DMEM10 was added, and cells were centrifuged. A small volume of $\mathrm{NaCl}$ was then used to incorporate the cells in the gels. A 96 well plate was used to prepare the gels, which had a volume of $75 \mu$ l each and 6,000 hFBs. One hour after the gels had been prepared, $100 \mu \mathrm{l}$ of culture media DMEM10 were added to each well, and left undisturbed for 20 hours in a $37^{\circ} \mathrm{C}, 5 \% \mathrm{CO}_{2}$ oven.

hFBs metabolic activity was quantified by Alamar Blue assay at days 1, 7, 14 and 21. At each time point, a $3 \mathrm{~mL}$ stock solution with $2700 \mu \mathrm{l}$ DMEM10 and $300 \mu \mathrm{l}$ of Alamar Blue (Thermo Fisher Scientific) reagent was prepared. Culture medium was removed from the gels and they were then covered with $100 \mu \mathrm{l}$ of the new medium containing Alamar Blue reagent, and incubated $\left(37^{\circ} \mathrm{C}, 5 \% \mathrm{CO}_{2}\right)$ for 3 hours. After incubation, $75 \mu \mathrm{l}$ of media from each sample was transferred to another 96well plate, and fluorescence was measured at 530nm with Synergy HTX multimode reader (BioTek).

\section{Primary Human Keratinocyte Viability}

For this study, primary human keratinocytes (hKCs) were used. Cells were routinely grown in CNT57 medium, (CELLnTEC). This medium was changed every 3 days, and cells were maintained at $37^{\circ} \mathrm{C}, 5 \% \mathrm{CO}_{2}$.

Plasma-PEG gel samples of $75 \mu$ leach were prepared for all compositions on a 96 well 
plate, following the protocol previously described. They were then covered with $100 \mu$ l of DMEM10 for 4 hours, allowing excess $\mathrm{CaCl} 2$ to leech out from the gel, in order to avoid hKCs differentiation. Meanwhile, CNT57 medium was removed from the plated hKCs, which were then detached using $1 \mathrm{~mL}$ of Trypsin (Sigma Aldrich). A volume of $5 \mathrm{~mL}$ of CNT57 media was added and the solution was further centrifuged. The medium covering the gels was removed, and 10,000 hKCs were added to each well in $100 \mu \mathrm{l}$ of CNT57 media. Gels were left undisturbed in a $37^{\circ} \mathrm{C}$ incubator for 3 days.

hKC viability was assessed by MTS assay (Bio Vision). At day 3, MTS reagent was thawed in a $37^{\circ} \mathrm{C}$ water bath. A volume of $20 \mu \mathrm{l}$ was added to each well already containing $100 \mu \mathrm{l}$ of media, and incubated for 2 hours $\left(37^{\circ} \mathrm{C}, 5 \% \mathrm{CO} 2\right)$. The reaction was then stopped by adding $25 \mu \mathrm{l}$ of $10 \%$ sodium dodecyl sulfate (SDS) to each gel. Aliquots of $75 \mu$ l were removed from each well, and absorbance was measured at 490nm with Synergy HTX multimode reader (BioTek).

\section{Results}

\section{Plasma-PEG Gel Synthesis}

Gels with varying PEG content $(0.125 \%$, $0.25 \%, 0.5 \%, 1 \%)$ were synthesized and compared to regular plasma gels $(0 \%)$ (Figure 2). A difference in colour could be observed between the current plasma gel and the gels containing different PEG contents, as well as an apparent increase in swelling in gels containing PEG. It was also observed that the incorporation of PEG improved gel rigidity and resilience against manipulation.

\section{Gelation time}

Plasma gels ( $0 \%$ PEG) were formed in about 12 minutes, and it could be observed that the incorporation of PEG affected and delayed the gelation time (Figure 3). Plasma gels (0\% PEG) were formed in about 12 minutes, and it could be observed that the incorporation of PEG affected and delayed the gelation time. As PEG content increased, gelation time increased as well. Gels with final PEG content of $0.125 \%$ and $0.25 \%$ showed very similar ge-

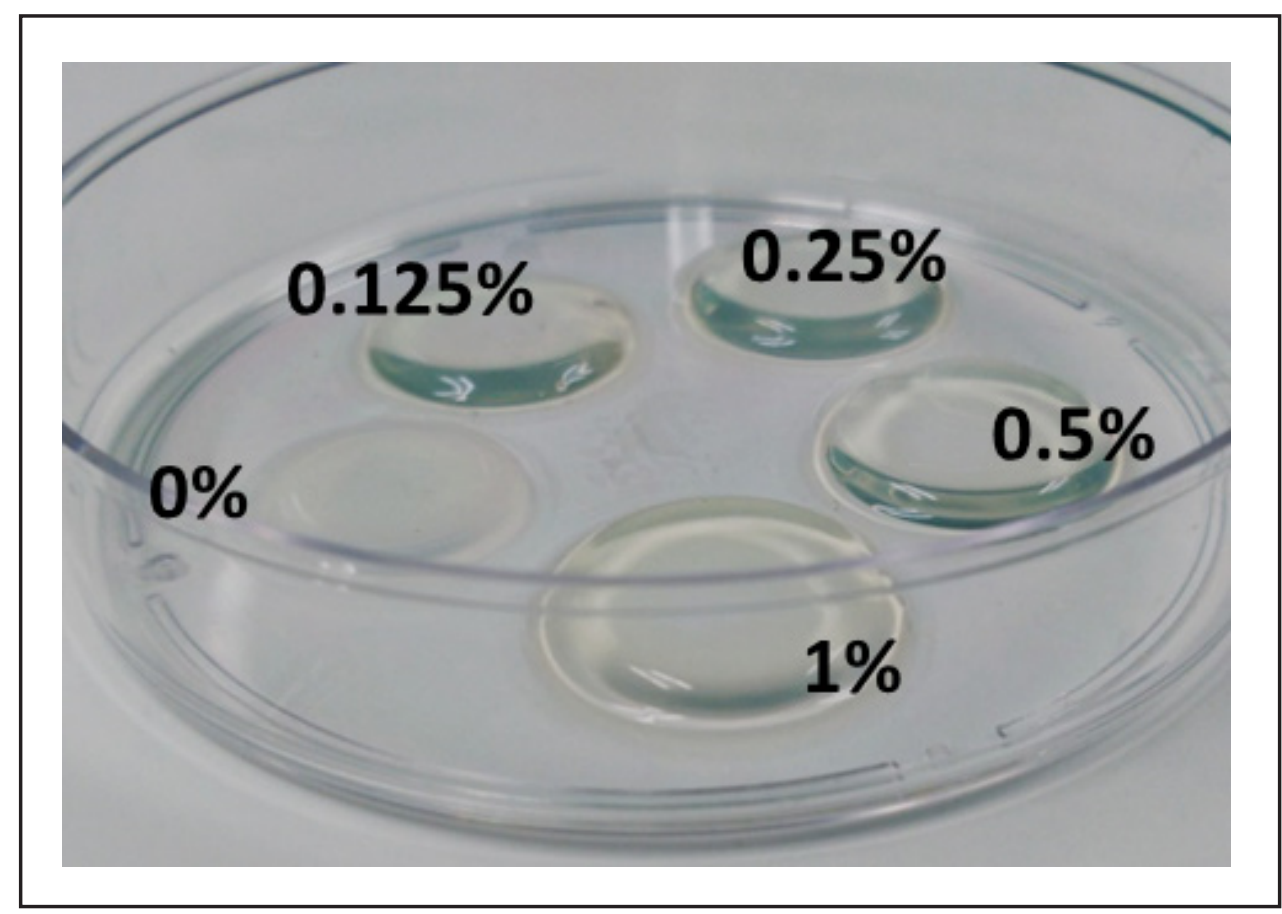

Figure 2. Different tested gel compositions. Percentages indicate total PEG content of each plasmaPEG gel (\% w/v). 
lation times, around 13 minutes. When PEG content was increased to $0.5 \%$ total, gelation took place in 15 minutes, and when this PEG content was doubled (1\%), gelation time increased to 19 minutes. Therefore, $0 \%$ and $1 \%$ PEG gels gelation times differed by about 8 minutes.

\section{Mass Swelling}

The addition of an interpenetrating PEG network to the plasma gels had a noticeable effect on the swelling behaviour of the gels, especially during the first 24 hours, where plasma gels have a high tendency to contract (Figure 4). Gels with $0.125 \%$, $0.25 \%$ and $0.5 \%$ PEG show a lower tendency to contract in relation to plasma gels. Maximum swelling was observed for $1 \%$ plasma-PEG gels.

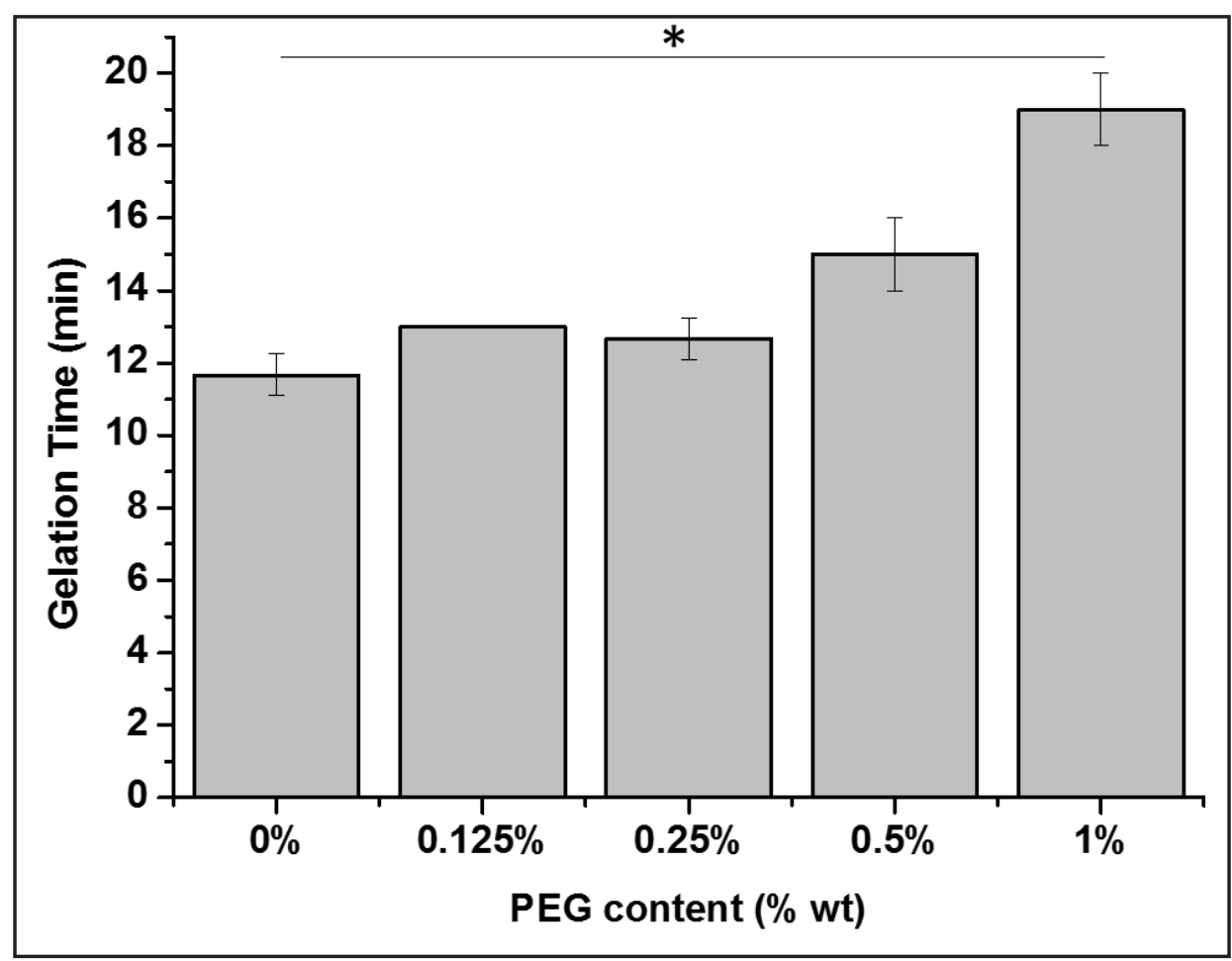

Figure 3. Gelation time at $37^{\circ} \mathrm{C}$ for each gel compositions $(n=3)$. Data are reported as mean \pm SD; asterisk denotes a significant difference between the $0 \%$ and $1 \%$ compositions $(p<0.05)$.

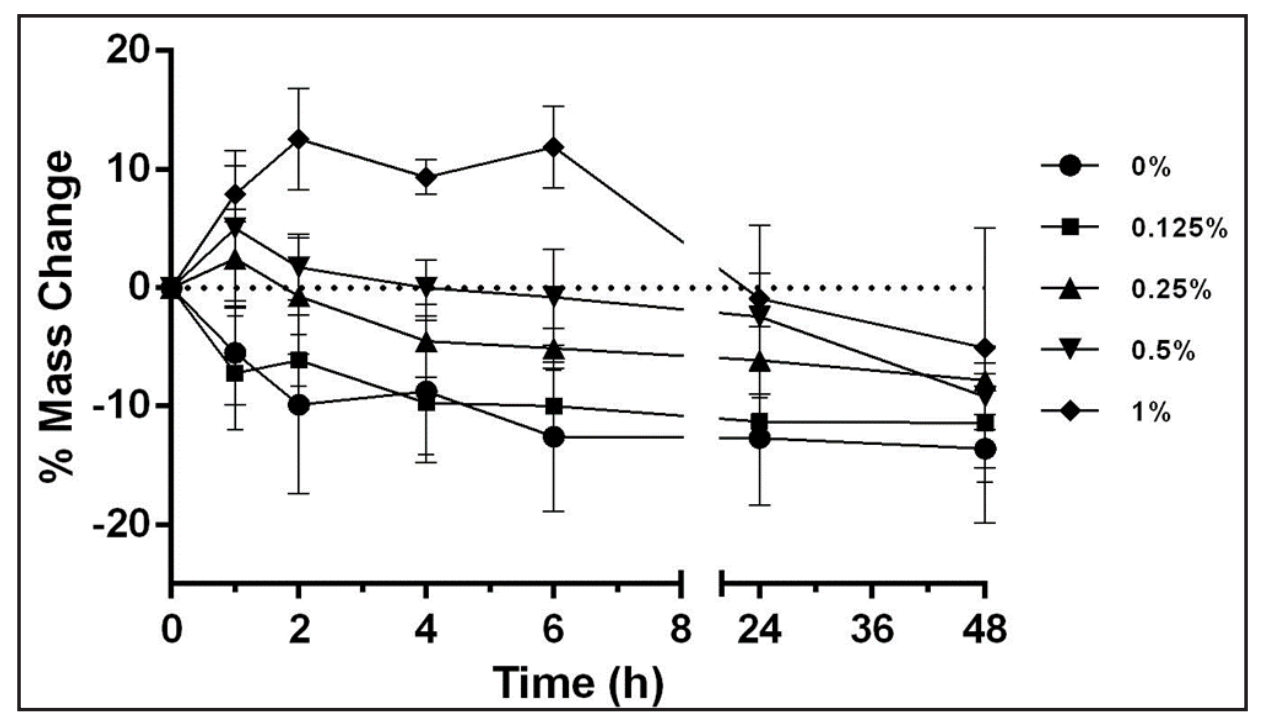

Figure 4. Temporal swelling in $1 \mathrm{XPBS}(3 \mathrm{~mL})$ at $37^{\circ} \mathrm{C}$ over 48 hours for each scaffold composition $(n=3)$. Insert shows a magnified view of the first 6 hours. Percentages indicate \% w/v PEG content. 
A Bradford assay was performed at the same time as the swelling study. Gels were embedded in $3 \mathrm{~mL}$ of 1 XPBS. In order to quantify protein release, $20 \mu$ of 1 XPBS were removed from each gel for every time point, and the Bradford assay was performed. A cumulative protein release curve was obtained (Figure 5). The incorporation of an interpenetrating PEG networks in the plasma hydrogels results in a lower amount of protein release.

\section{Embedded Human Fibroblast Viability}

An increase in cell proliferation could be observed in all gel compositions between day 1 and 14 (Figure 6), and by day 14 cells from different gel compositions reached very similar metabolic activities. In addition, hFBs morphology was verified by contrast phase microscopy during the experiment.

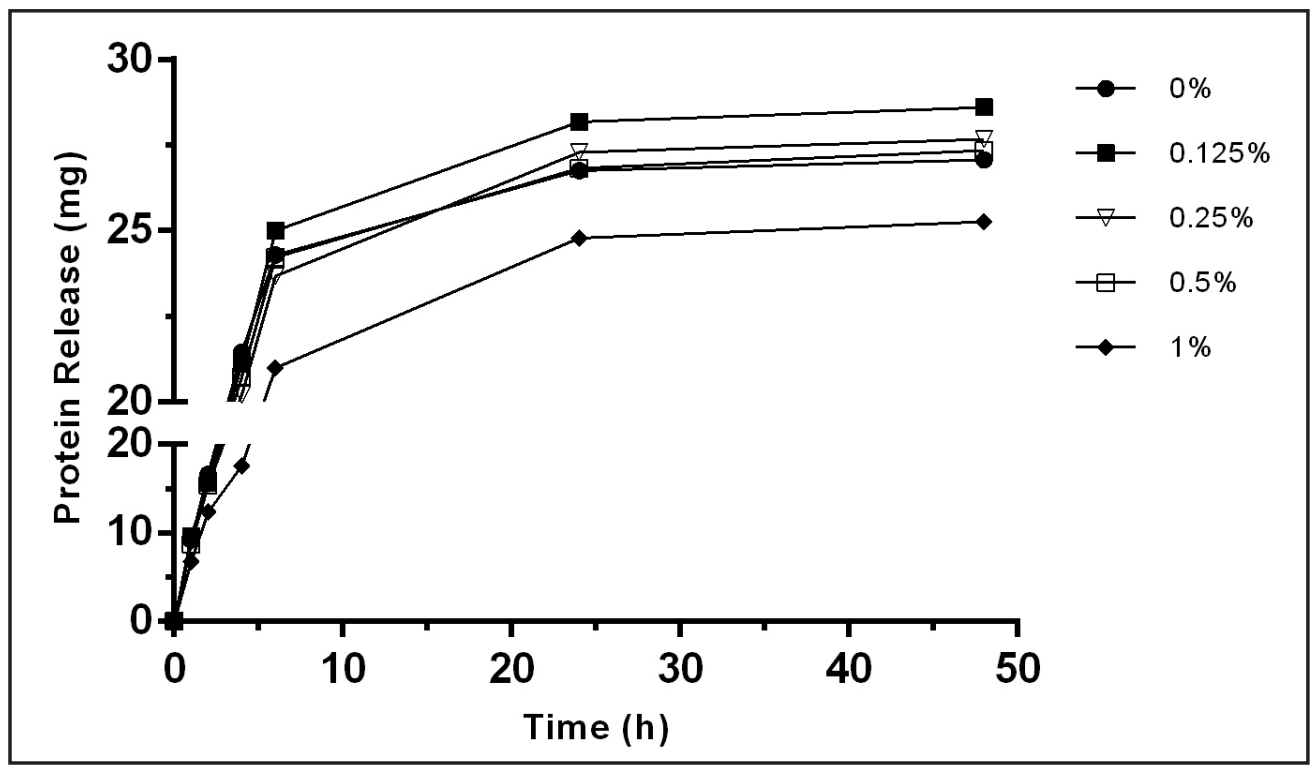

Figure 5. Cumulative protein release during 48 hours for each scaffold composition $(n=3)$.

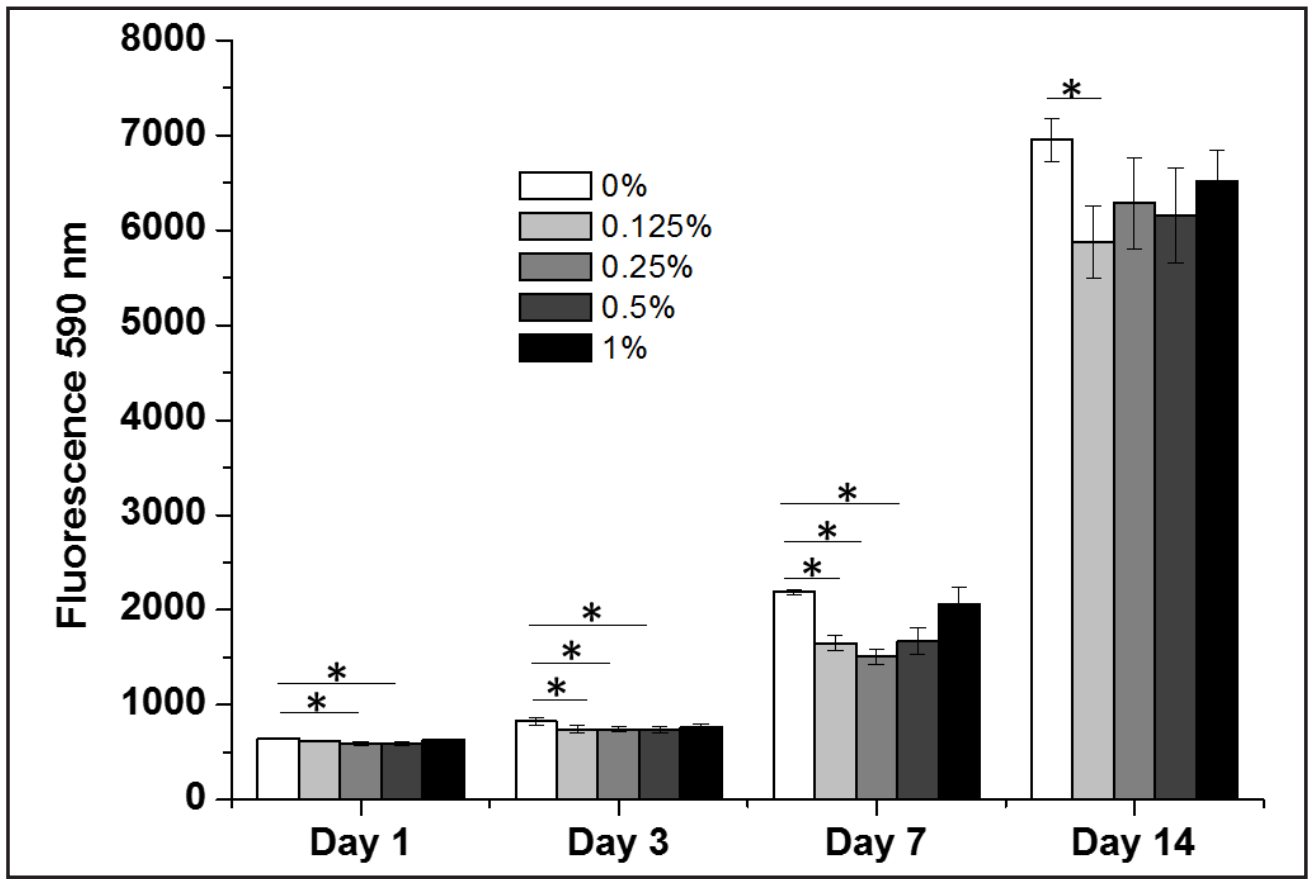

Figure 6. Alamar Blue cell metabolic assay for embedded human fibroblasts in 96-well plate over time. Data are reported as mean $\pm \mathrm{SD}(\mathrm{n}=4)$; asterisks denote difference between populations $(\mathrm{p}<0.05)$. 


\section{Primary Human Keratinocyte Viability}

MTS assay was performed at day 3 for all scaffold compositions (Figure 7). It could be observed how metabolic output from cells within gels containing PEG was 15-20\%lower compared to regular plasma gel (0\%) after 72 hours.

\section{Discussion}

The goal of this project was to modulate the physical behaviour of autologous human plasma-based biological skin scaffolds without affecting cell viability. A platform was designed, where 4A-PEG and 4SG-PEG were introduced into the existing human plasma-based scaffold protocol in the form of an interpenetrating polymer network. Amine reactive $4 \mathrm{SG}$ PEG reacts covalently with amine terminated 4A-PEG, fibrinogen and plasma proteins, forming a PEG-fibrin network hydrogel.

Gelation time measurements showed that gelation was delayed as total PEG concentra- tion was increased. This delay can be attributed to competitive covalent inibition (4SG-PEG reacting with fibrinogen's free amino groups) and non-competitive physical inhibition of PEG molecules with normal fibrin formation. However, gelation times are still suitable for clinical application. The mass swelling ratio of each gel composition was assessed, and it was demonstrated that the capacity of each gel to swell was increased as a function of total PEG content, due to the hydrophilicity of PEG molecule (26). Therefore, when 4A-PEG and 4SG-PEG are introduced into the plasma scaffolds, hydrogel content is increased. Incorporation of PEG network also helped to reduce protein release. Studies have shown that when increasing the amount of PEG in hydrogels, there is a decrease in the amount of protein release, caused by the additional crosslinks in the overall scaffold (27). This is important when involving dermo-epidermal substitutes, as plasma proteins play an important role in wound healing by accelerating tissue repair

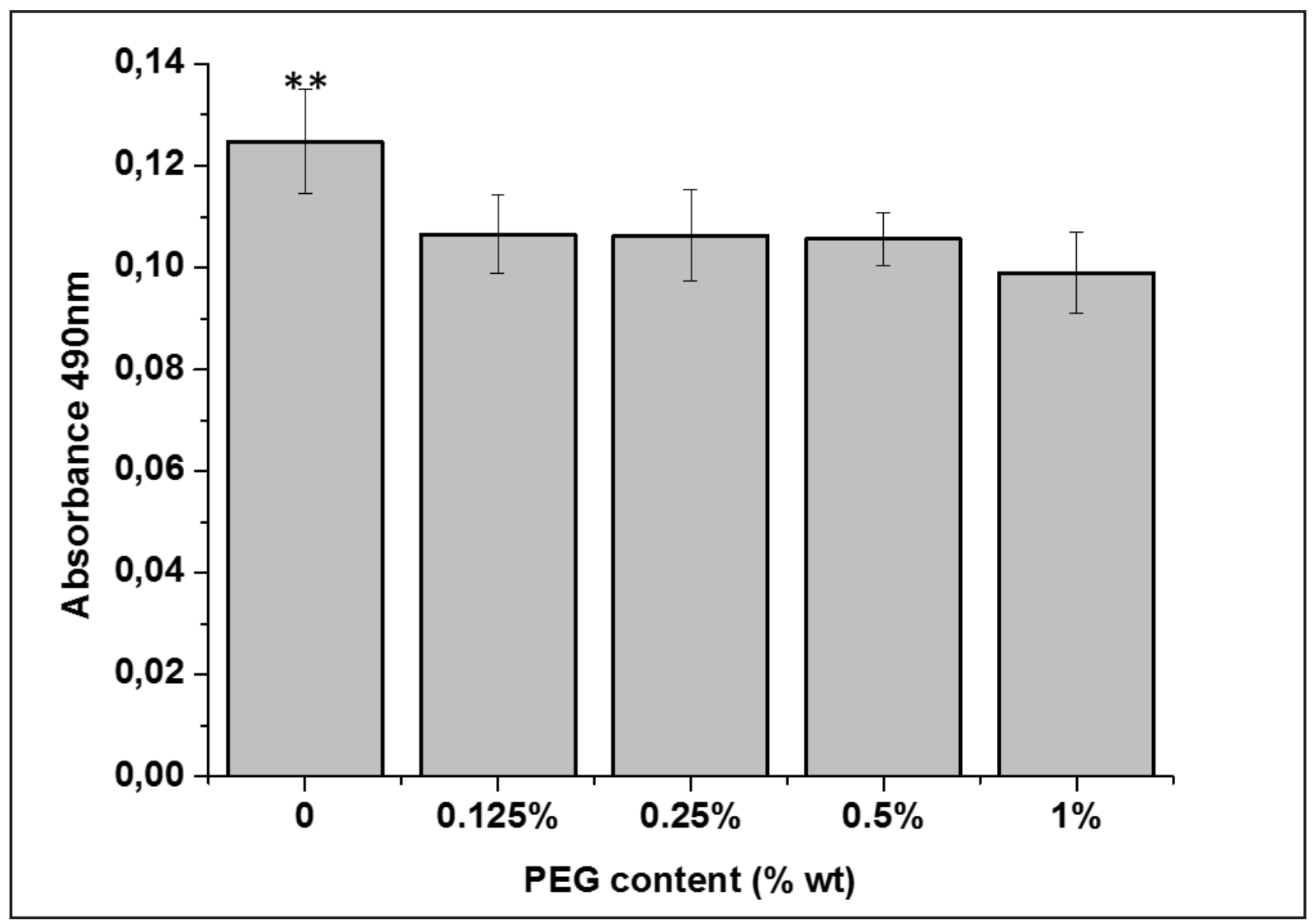

Figure 7. MTS cell viability assay for primary human keratinocytes after 3 days. Data are reported as mean $\pm \mathrm{SD}(\mathrm{n}=8)$; asterisks denote that $0 \%$ is different from all other compositions $(\mathrm{p}<0.01)$. 
and cell migration, preventing autoimmune reactions, reducing inflammatory response, and inhibiting microbial invasion (28).

Regarding in vitro assessment, $\mathrm{hFBs}$ proliferation increased in all scaffold compositions between day 1 and 14, which confirms the biocompatibility of the synthetic polymer PEG. However, incorporating PEG into the system increased the overall degree of crosslinking in the gel network. Studies have shown that increased degree of crosslinking increases the stiffness of the environment, causing limitations for cell elongation, migration and proliferation, which could have led to a slight decrease in hFB proliferation up to day 7 (29). However, high protein content help regulate cell proliferation and survival, which might have helped counteract this effect in the longterm (30). Thje MTS assay showed a slight decrease in hKC metabolic output in gels containing PEG, which is likely due to PEG's non adhesiveness to cells (31).

\section{Conclusion}

Mechanical behaviour of the new scaffolds was assessed by mass swelling, protein release, and gelation time. Increasing PEG content delayed gelation, possibly caused by competitive covalent and non-competitive physical inhibition with normal fibrin formation, but gelation times remained clinicaly viable. Plasma gel contractibility was decreased as hydrogel content was increased, and the addition of the PEG network helped reduce protein leeching. Elasticity and ease of handling was improved as PEG content increased. Regarding cell viability, hFB and hKCs proliferation were assessed by Alamar Blue and MTS assays respectively. Results indicated a slight decrease in $\mathrm{hFB}$ proliferation as crosslinking increased, and suggested a decrease in hKC adhesion to the scaffold when PEG was present. This project demonstrated a platform that has potential to modulate the physical behaviour of human plasma-based biological skin scaffolds while having only mild effects on hFB and hKC viability.

\section{References}

1. Horch RE, Kopp J, Kneser U, Beier J, Bach AD. Tissue engineering of cultured skin substitutes. J Cell Mol Med. 2005;9(3):592-608.

2. Pham C, Greenwood J, Cleland H, Woodruff P, Maddern G. Bioengineered skin substitutes for the management of burns: A systematic review. Burns. 2007;33(8):946-57.

3. Sheridan R. Closure of the excised burn wound: autografts, semipermanent skin substitutes, and permanent skin substitutes. Clin. Plast. Surg. 2009;36:643-51

4. Andreassi A, Bilenchi R, Biagioli M, D’Aniello C. Classification and pathophysiology of skin grafts Clin. Dermatol. 2005;23:332-337.

5. SuppDMand Boyce $\mathbf{S}$ T. Engineered skin substitutes: practices and potentials. Clin. Dermatol. 2005;23:403-412.

6. Shevchenko RV, James SL, James SE. A review of tissue-engineered skin bioconstructs available for skin reconstruction. J R Soc Interface. 2010;7(43):229-258.

7. Atiyeh BS, Costagliola M. Cultured epithelial autograft (CEA) in burn treatment: three decades later Burns 2007;33:405-413.

8. Shevchenko RV, James SL, James SE. A review of tissue-engineered skin bioconstructs available for skin reconstruction. J R Soc Interface. 2010;7(43):229-258.

9. MacNeil S. Progress and opportunities for tissueengineered skin. Nature. 2007;445:874-880.

10. Llames SG, Del Rio M, Larcher F, García E, García M, Escamez MJ, et al. Human plasma as a dermal scaffold for the generation of a completely autologous bioengineered skin. Transplantation. 2004;77(3):350-355.

11. Llames $\mathbf{S}$ et al. Clinical results of an autologous engineered skin. Cell Tissue Bank. 2006;7:47-53.

12. Gonzalez de Torre I, Weber M, Quintanilla L, Alonso M, Jockenhoevel S, Rodríguez Cabello JC, et al. Hybrid elastin-like recombinamer-fibrin gels: physical characterization and in vitro evaluation for cardiovascular tissue engineering applications. Biomater Sci. 2016;4(9):1361-1370.

13. Scionti G, Moral M, Toledano M, Osorio R, Durán JDG, Alaminos M, et al. Effect of the hydration on the biomechanical properties in a fibrinagarose tissue-like model. J Biomed Mater Res A. 2014;102(8):2573-2582.

14. Jiang B, Waller TM, Larson JC, Appel AA, Brey EM. Fibrin-loaded porous poly(ethylene glycol) hydrogels as scaffold materials for vascularized tissue formation. Tissue Eng Part A. 2013;19(12):224-234.

15. Zhu J, Marchant RE. Design properties of hydrogel tissue-engineering scaffolds. Expert Rev Med Devices. 2011;8(5):607-626.

16. Hutanu D, Frishberg MD, Guo L, Darie CC. Re- 
cent Applications of Polyethylene Glycols (PEGs) and PEG Derivatives. Mod Chem Appl [Internet]. 2014 Aug 26

17. Zhu J. Bioactive modification of poly(ethylene glycol) hydrogels for tissue engineering. Biomaterials. 2010;31(17):4639-4656.

18. Banerjee SS, Aher N, Patil R, Khandare J, Banerjee SS, Aher N, et al. Poly(ethylene glycol)-Prodrug Conjugates: Concept, Design, and Applications. Journal of Drug Delivery. 2012;2012:ID103973.

19. Lin C-C, Anseth KS. PEG Hydrogels for the Controlled Release of Biomolecules in Regenerative Medicine. Pharm Res. 2009;26(3):631-643.

20. Song A, Rane AA, Christman KL. Antibacterial and cell-adhesive polypeptide and poly(ethylene glycol) hydrogel as a potential scaffold for wound healing. Acta Biomater. 2012;8(1):41-50.

21. Wallace DG, Cruise GM, Rhee WM, Schroeder JA, Prior JJ, Ju J, et al. A tissue sealant based on reactive multifunctional polyethylene glycol. J Biomed Mater Res. 2001;58(5):545-555.

22. Behrens AM, Lee NG, Casey BJ, Srinivasan P, Sikorski MJ, Daristotle JL, et al. BiodegradablePolymer-Blend-Based Surgical Sealant with Body-Temperature-Mediated Adhesion. Adv Mater. 2015;27(48):8056-8061.

23. Phelps EA, Enemchukwu NO, Fiore VF, Sy JC, Murthy N, Sulchek TA, et al. Maleimide CrossLinked Bioactive PEG Hydrogel Exhibits Improved Reaction Kinetics and Cross-Linking for Cell Encapsulation and In Situ Delivery. Adv Mater. 2012;24(1):64-70.

24. Sakai T, Matsunaga T, Yamamoto Y, Ito C, Yo- shida R, Suzuki S, et al. Design and Fabrication of a High-Strength Hydrogel with Ideally Homogeneous Network Structure from Tetrahedron-like Macromonomers. Macromolecules. 2008;41(14):5379-5384.

25. Technical Manual (11th ed). Walker $\mathrm{RH}$, ed. Bethesda, MD: American Association of Blood Banks, 1993, pp 728-730.

26. Banerjee SS, Aher N, Patil R, Khandare J. Poly(ethylene glycol)-Prodrug Conjugates: Concept, Design, and Applications. J Drug Deliv. 2012;2012:e103973

27. Lin C-C, Anseth KS. PEG Hydrogels for the Controlled Release of Biomolecules in Regenerative Medicine. Pharm Res. 2009;26(3):631-643.

28. O'Toole EA, Mellerio JE. Wound healing. In: Burns DA, Breathnach SM, Cox N, Griffiths C, eds. Rook's Textbook of Dermatology, 8th edition, Oxford: Wiley-Blackwell; 2010; p. 1-27.

29. Chen $X$, Thibeault SL. Biocompatibility of a synthetic extracellular matrix on immortalized vocal fold fibroblasts in $3 \mathrm{~d}$ culture. Acta Biomater. 2010;6(8):2940-2948.

30. Mazzucotelli JP, Klein-Soyer C, Beretz A, Brisson C, Archipoff G, Cazenave JP. Endothelial cell seeding: coating Dacron and expanded polytetrafluoroethylene vascular grafts with a biological glue allows adhesion and growth of human saphenous vein endothelial cells. Int J Artif Organs. 1991;14(8):482-490.

31. Lensen MC, Schulte VA, Diez M. Cell Adhesion and Spreading on an Intrinsically Anti-Adhesive PEG Biomaterial. In: Pignatello R, editor. Biomaterials - Physics and Chemistry [Internet]. InTech; 2011. 